\title{
Cerium Oxide Nanoparticles Decrease Drought-Induced Oxidative Damage in Sorghum Leading to Higher Photosynthesis and Grain Yield
}

\author{
Maduraimuthu Djanaguiraman, ${ }^{\dagger, \|}$ Remya Nair, ${ }^{\ddagger}$ Juan Pablo Giraldo, \\ and Pagadala Venkata Vara Prasad*, ${ }^{*}$
}

${ }^{\dagger}$ Department of Agronomy, Throckmorton Plant Science Center, Kansas State University, Manhattan, Kansas 66506, United States

${ }^{\ddagger}$ Department of Energy, Environmental and Chemical Engineering, Washington University in St. Louis, St. Louis, Missouri 63130, United States

${ }^{\S}$ Department of Botany and Plant Sciences, University of California, Riverside, California 92521, United States

"Department of Nano Science and Technology, Tamil Nadu Agricultural University, Coimbatore, Tamil Nadu 641003, India

\section{Supporting Information}
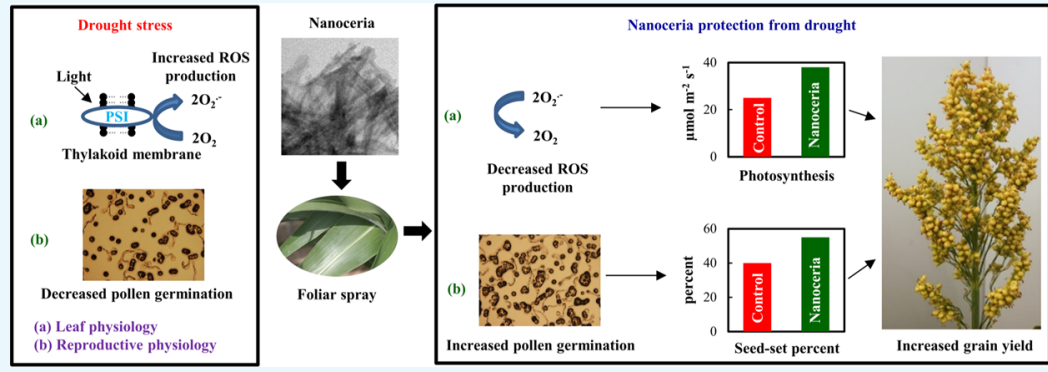

ABSTRACT: Drought is a major abiotic stress affecting crop growth and yield worldwide. Drought-induced oxidative stress results in the reduction of plant photosynthesis and reproductive success. Cerium oxide nanoparticles (nanoceria) possess potent antioxidant properties that can alleviate drought-induced oxidative stress by catalytic scavenging reactive oxygen species (ROS), thereby protecting sorghum [Sorghum bicolor (L.) Moench] photosynthesis and grain yield. Drought was imposed at the booting stage by withholding water for $21 \mathrm{~d}$. Foliar-sprayed nanoceria $\left(10 \mathrm{mg} \mathrm{L}^{-1}\right)$ efficiently reduced leaf superoxide radical (41\%) and hydrogen peroxide (36\%) levels and decreased cell membrane lipid peroxidation (37\%) under drought. Nanoceria increased leaf carbon assimilation rates $(38 \%)$, pollen germination $(31 \%)$, and seed yield per plant (31\%) in drought-stressed plants relative to water-sprayed controls. Translocation study indicated that nanoceria can move from root to shoot of sorghum plants. Toxicity assays in mammalian cells indicated that nanoceria effective concentration $(\mathrm{EC})_{50}$ of $>250 \mathrm{mg} \mathrm{L}^{-1}$ is well above the concentration used in this study. Foliar-sprayed nanoceria protect sorghum plants from oxidative damage under drought stress leading to higher grain yield.

\section{INTRODUCTION}

Nanotechnology is a transdisciplinary cutting-edge tool with large potential in agricultural science to improve crop productivity. Metallic nanoparticles of varying size, concentration, and surface charge have been reported to influence the growth and development in diverse plant species. ${ }^{1}$ Cerium is a rare earth metal that exists as either free metal or oxide form and can cycle between the cerous $\left(\mathrm{Ce}^{3+}\right)$ and ceric $\left(\mathrm{Ce}^{4+}\right)$ oxidation states acting as oxygen buffer. ${ }^{2,3}$ Cerium oxide forms oxygen vacancies or defects in the lattice structure by loss of oxygen and/or its electrons. ${ }^{2,3}$ The valence and structure of cerium oxide are dynamic and change spontaneously. ${ }^{4}$ Nanoceria have chemical and physical properties similar to bulk cerium but has an exceptional catalytic property because of its increased surface area and oxygen vacancies. ${ }^{5}$ The ratio of $\mathrm{Ce}^{3+} / \mathrm{Ce}^{4+}$ sites on the surface of nanoceria is strongly correlated with its antioxidant-enzyme-mimetic activity. ${ }^{6,7}$ Pulido-Reyes et al. ${ }^{8}$ showed that nanoceria with low $\mathrm{Ce}^{3+} / \mathrm{Ce}^{4+}$ ratio exhibit catalase (CAT) and superoxide dismutase (SOD) mimetic activity and scavenge $\mathrm{H}_{2} \mathrm{O}_{2}$ and superoxide radical. To our knowledge, the role of nanoceria in alleviating droughtinduced oxidative damage has not been studied.

Drought is an important abiotic stress that limits the productivity of major food crops across the globe. The Intergovernmental Panel on Climate Change has predicted that arid and semiarid regions of the world where sorghum [Sorghum bicolor (L.) Moench] is grown for food and nutritional security will experience a substantial change in

Received: September 25, 2018

Accepted: October 15, 2018

Published: October 31, 2018 
(a)
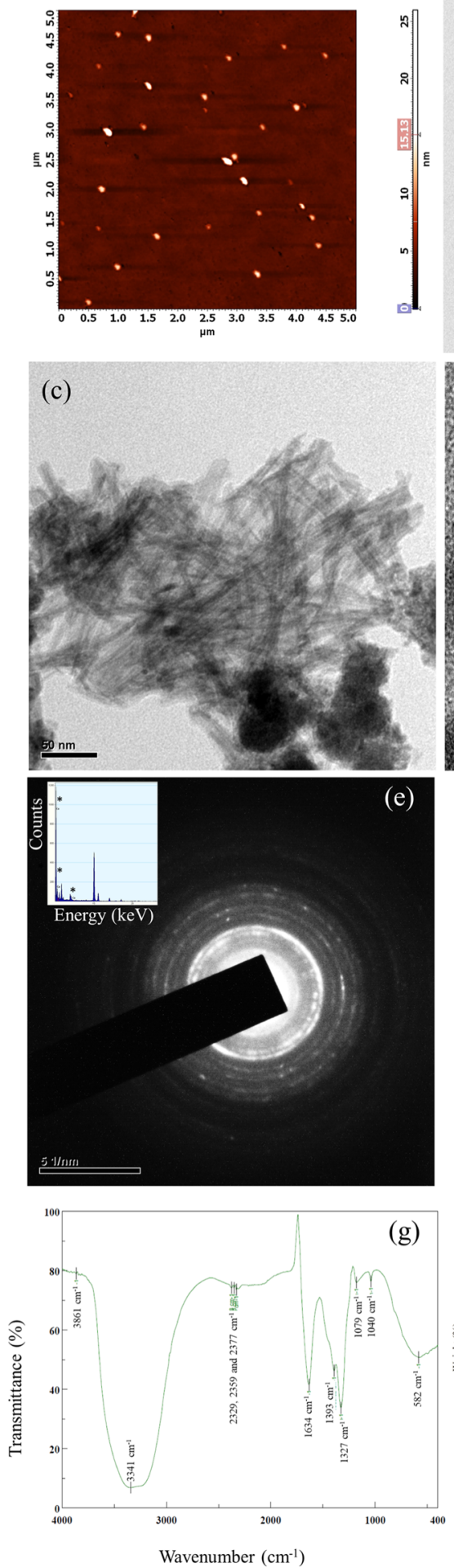
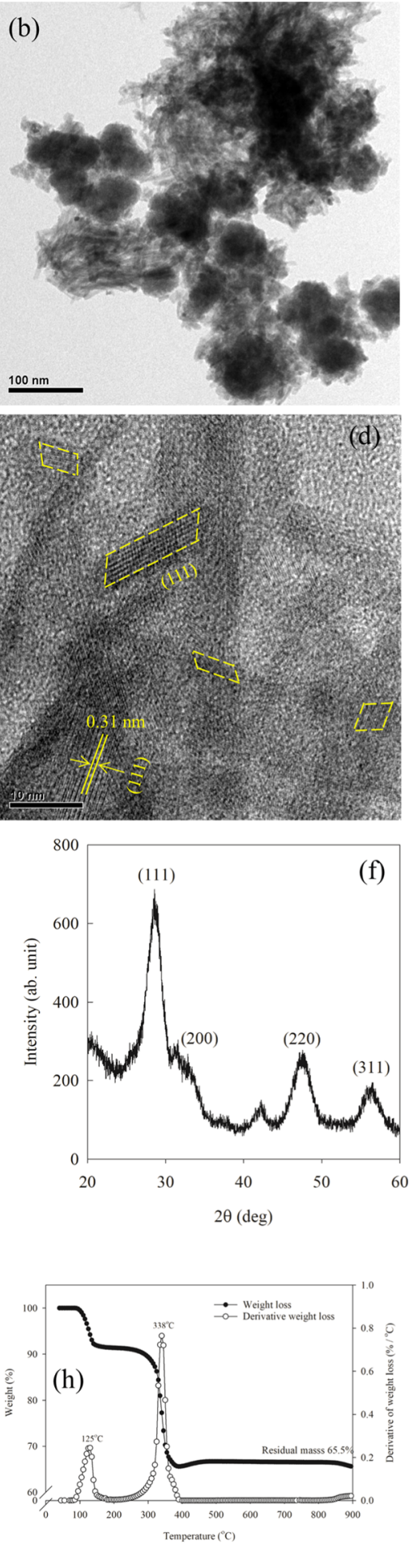

Figure 1. Representative (a) AFM, (b) TEM, (c,d) HRTEM, (e) SAED, the insert showing the EDX analysis, (f) powder XRD pattern, (g) FT-IR, and (h) TGA image of synthesized nanoceria. (a) AFM image of nanoceria showing the particle size of $15 \mathrm{~nm}$. (b) Low-resolution TEM image showing rod-shaped nanoceria. (c) HRTEM image showing rod-shaped nanoceria. (d) Cubic phase nanoceria with a $d$ spacing of $0.31 \mathrm{~nm}$. (e) SAED pattern confirms the presence of cubic shape and its inset showing the purity of synthesized nanoceria. (f) Cubic phase of nanoceria was identified by a strong peak of the (111) plane, which corresponds to the interplanar spacing of $0.31 \mathrm{~nm}$. The sharpness of the diffraction peaks suggests that the product is well crystallized. (g) FT-IR spectrum of nanoceria showing four intense absorption bands at 3341, 1634, 1327, and 582 $\mathrm{cm}^{-1}$. (h) Complete weight loss at around $400{ }^{\circ} \mathrm{C}$ indicates the pure phase of $\mathrm{CeO}_{2}$.

the frequency and intensity of precipitation along with prolonged periods of water stress and high temperatures. ${ }^{9}$ Sorghum grain yield is severely decreased by drought. ${ }^{10,11}$
Simulation models have predicted that mean sorghum yields will decrease in the next decades by $27 \%$ in Australia, ${ }^{12} 3-16 \%$ in India, ${ }^{13} 7-47 \%$ in sub-Saharan Africa, ${ }^{14}$ and $11-17 \%$ in 
Mali $^{15}$ because of drought. It is therefore critical to develop novel agricultural technologies for protecting and increasing sorghum grain yield under drought. In arid and semiarid regions, plants experience drought because of limited water availability and increased water loss from soil through evaporation and transpiration. ${ }^{16,17}$ Although a primary physiological effect of drought was decreased stomatal conductance, ${ }^{18}$ both stomatal and nonstomatal limitations are reported to be responsible for decreased photosynthetic rate under drought. ${ }^{19-21}$ The relative effects of stomatal and nonstomatal limitations on photosynthetic rates are speciesdependent, ${ }^{21}$ and plant responses to drought within the species are also genotype-specific. ${ }^{22} \mathrm{~A}$ main cause for decreased photosynthetic rate in plants including sorghum is the reduction of $\mathrm{CO}_{2}$ movement from atmosphere to the sites of carbon assimilation in the chloroplasts ${ }^{17,23-26}$ because of stomatal closure, leading to enhancement in the production of reactive oxygen species [ROS, viz., superoxide radical $\left(\mathrm{O}_{2}{ }^{-}\right)$, hydrogen peroxide $\left(\mathrm{H}_{2} \mathrm{O}_{2}\right)$, hydroxyl radical $\left(\mathrm{OH}^{\bullet}\right)$, singlet oxygen $\left({ }^{1} \mathrm{O}_{2}\right)$, etc.)] in chloroplasts. ${ }^{27,28}$ ROS can directly attack DNA, ${ }^{2,30}$ proteins, ${ }^{29,30}$ and lipid membranes, leading to oxidative damage. ${ }^{31,32}$ Herein, we postulate that the nanoceria catalytic ROS scavenging ability has the potential to reduce ROS levels and alleviates the detrimental effects of oxidative stress under drought.

To counteract the damaging effects of ROS accumulation under stress, plants rely on antioxidative defense systems either through enzymatic or nonenzymatic pathways. ROS scavenging enzymes including SOD, CAT, and peroxidases (POXs) and antioxidants such as ascorbic acid, tocopherols, glutathione, proline, carotenoids, phenolic acids, and flavonoids that are involved in detoxification of $\mathrm{ROS}^{29}$ Under normal conditions, the homeostasis between ROS and antioxidative enzyme activity is maintained; however, under drought, this balance is disrupted because of the elevated levels of ROS, leading to oxidative burst and decreased antioxidants. ${ }^{33} \mathrm{We}$ hypothesized that nanoceria long-term catalytic scavenging of ROS protects photosynthetic rates and grain yield of sorghum under drought conditions. The main objectives of this study were to quantify the impact of nanoceria on (i) leaf ROS levels and antioxidant enzyme activity, (ii) pollen germination and seed yield, and (iii) leaf carbon assimilation rates, stomatal conductance, and leaf anatomical traits of grain sorghum plants grown under drought stress.

\section{RESULTS AND DISCUSSION}

2.1. Nanoceria Characterization. The size and morphology of nanoceria were measured by atomic force microscope (AFM) and transmission electron microscopy (TEM), respectively. The AFM images indicate that the synthesized nanoceria have an average diameter of $15 \pm 5 \mathrm{~nm}$ (Figure 1a). The TEM images show that the synthesized nanoceria are rodshaped (Figure 1b) and the detailed morphological and structural analysis of nanoceria using a high-resolution TEM (HRTEM) revealed a strong presence of $\{111\}$ facets (Figure $1 \mathrm{c}, \mathrm{d})$. The nanoceria were well crystallized with distinctive set of fringes unambiguously identified as the (111) plane of cerium oxide $\left(\mathrm{CeO}_{2}\right)$, implying that the nanoparticles were predominantly exposed to the (111) plane and the corresponding interplanar spacing was $0.31 \mathrm{~nm}$ (Figure 1d). The selected-area diffraction pattern of nanoceria (Figure 1e) and crystallites could be indexed to (111), (200), (220), and (311) reflection planes of the cubic structure. The energy- dispersive X-ray spectroscopy (EDX) spectra of the synthesized nanoceria confirm the presence of $\mathrm{Ce}$ and $\mathrm{O}$ elements with no impurities (insert Figure 1e). The X-ray diffraction (XRD) confirmed the crystalline nature of nanoceria. The diffraction peaks due to (111), (200), (220), and (311) planes of nanoceria at $2 \theta$ of $28.6^{\circ}, 32.8^{\circ}, 47.8^{\circ}$, and $56.7^{\circ}$, respectively, were consistent with the cubic structure of the $\mathrm{CeO}_{2}$ nanoparticle (JCPDS 89-8436; Figure 1f). The Fourier transform infrared (FT-IR) spectroscopy spectrum of nanoceria shows four intense absorption bands at 3341, 1634, 1327, and $582 \mathrm{~cm}^{-1}$ (Figure $1 \mathrm{~g}$ ). The absorption band at $\sim 3341$ $\mathrm{cm}^{-1}$ was attributed to the $\mathrm{O}-\mathrm{H}$ mode, and the band at $\sim 1634$ $\mathrm{cm}^{-1}$ corresponds to the bending of $\mathrm{H}-\mathrm{O}-\mathrm{H}$ which partly overlapped with the $\mathrm{O}-\mathrm{C}-\mathrm{O}$ stretching band. ${ }^{34,35}$ The band at $\sim 1327$ and $582 \mathrm{~cm}^{-1}$ was associated with $\mathrm{C}-\mathrm{H}$ bending and stretching frequency of $\mathrm{Ce}-\mathrm{O}$, respectively. ${ }^{36}$ By considering the relative intensity of the $\mathrm{Ce}-\mathrm{O}$ modes to the adsorbed $\mathrm{OH}$ compounds, it was clear that the synthesized nanoceria had high crystallinity and purity. The thermogravimetric analysis (TGA) curve of nanoceria (Figure 1h) showed two distinct peaks at 125 and $338{ }^{\circ} \mathrm{C}$. The weight loss from 100 to $200{ }^{\circ} \mathrm{C}$ was attributed to the loss of moisture and decomposition of the organic ligands. The second mass loss at $338{ }^{\circ} \mathrm{C}$ was ascribed to the burning of the residual organic contents. After $400{ }^{\circ} \mathrm{C}$, no change in weight was observed, indicating the pure phase of $\mathrm{CeO}_{2}$.

2.2. Impact of Nanoceria on Mammalian Cell Viability. The Organisation for Economic Cooperation and Development (OECD) recommends to analyze the safety of nanomaterials before their application to crops. To assess the potential toxicity effects of nanoceria on mammalian cells, we performed cell viability tests in murine cells exposed to different levels of nanoceria concentrations. The murine cell viability of control $\left(0 \mathrm{mg} \mathrm{L}^{-1}\right)$ was considered as $100 \%$, and the medium supplemented with nanoceria at concentrations of 100,250 , and $500 \mathrm{mg} \mathrm{L}^{-1}$ showed 25,28 , and $43 \%$ reduction in cell viability, respectively, over control (Figure 2a). The 4',6diamidino-2-phenylindole (DAPI) assay is widely used to differentiate normal and apoptotic cells through staining of nucleus and condensed chromosome (Figure $2 \mathrm{~b}-\mathrm{e}$ ). The results indicated that controls $\left(0 \mathrm{mg} \mathrm{L}^{-1}\right)$ that exhibit uniform staining of the nucleus with clear nuclear membranes were observed (Figure $2 \mathrm{~b}$ ). Similar results were observed at 100 and $250 \mathrm{mg} \mathrm{L}^{-1}$ concentrations (Figure $2 \mathrm{c}, \mathrm{d}$ ). However, at $500 \mathrm{mg}$ $\mathrm{L}^{-1}$, abnormal nuclear margins and nucleus staining were observed (Figure 2e). This indicates that nanoceria at concentrations of 100 and $250 \mathrm{mg} \mathrm{L}^{-1}$ did not damage most $(<28 \%)$ of the fibroblast L929 cells. The results were corroborated with an 3-(4,5-dimethylthiazolyl-2)-2,5-diphenyltetrazolium bromide (MTT) assay (Figure 2a). Previous studies have also shown that $\mathrm{LD}_{50}$ for nanoceria on various cell lines is more than $100 \mathrm{mg}$ of nanoceria $\mathrm{L}^{-1}$. $38-40$

2.3. Uptake of Nanoceria in Plants. Figure 3 shows cerium concentrations in shoot and root of the sorghum plant grown in acid-washed sand spiked with 50 and $100 \mathrm{mg} \mathrm{L}^{-1}$. The control leaf and root samples had a cerium concentration of $<0.05 \mathrm{mg} \mathrm{kg}^{-1}$. The cerium concentration in roots was significantly $(P \leq 0.001)$ higher than shoots at both 50 (1.5fold) and 100 (2.5-fold) $\mathrm{mg} \mathrm{L}^{-1}$ nanoceria concentration. Positive surface-charged nanoparticle-like $\mathrm{CeO}_{2}$ can accumulates on the root surface because of the presence of mucilage on the root surface, leading to reduced mobility from root to shoot. ${ }^{41}$ Apart from this, the shape of nanoceria also influences 


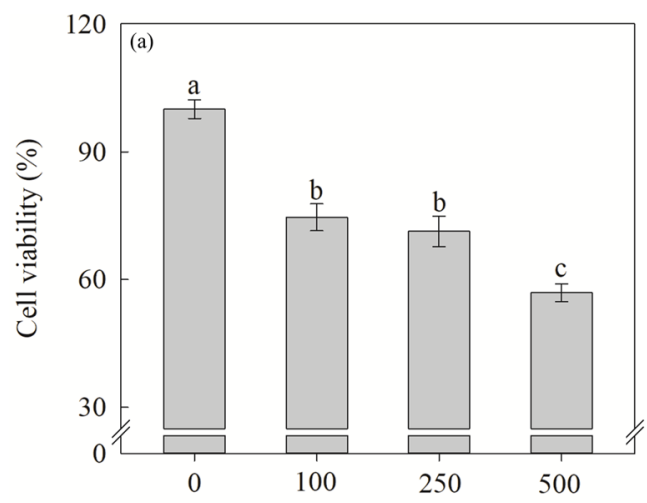

Concentration of nanoceria $\left(\mathrm{mg} \mathrm{L}^{-1}\right)$
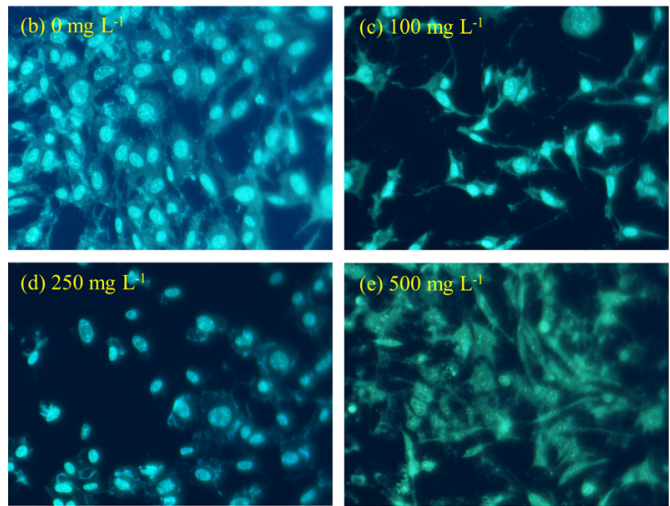

Figure 2. Effect of nanoceria on cell viability and membrane damage of murine cell line. (a) Cell viability assessment through MTT assay. (b) 0 , (c) 100 , (d) 250 , and (e) $500 \mathrm{mg} \mathrm{L}^{-1}$ of nanoceria on cell and nuclear membrane damage of murine cell line assessed through DAPI.

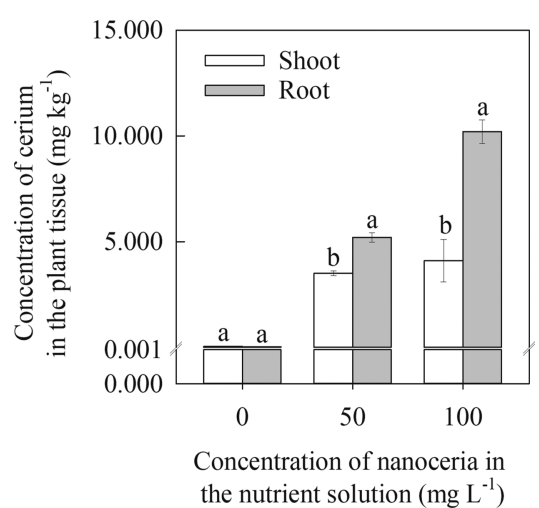

Figure 3. Translocation of nanoceria in sorghum plants. Concentration of nanoceria $\left(\mu \mathrm{g} \mathrm{g}^{-1}\right)$ in root and shoot of sorghum seedling grown in one-quarter strength of the Hoagland solution containing 0 , 50 , or $100 \mathrm{mg} \mathrm{L}^{-1}$ nanoceria. Each value is the mean $\pm \mathrm{SE}$ of five independent measurements. Means with different letters are significantly different at $P \leq 0.05$.

the translocation efficiency, for example, the translocation of rod-shaped nanoceria was more efficient than octahedral- or cubic-shaped nanoceria. ${ }^{42}$ However, translocation of nanoceria from root to shoots is strongly associated with the transformation of $\mathrm{CeO}_{2}$ within the cell. ${ }^{43}$ Biotransformation studies have indicated that cerium applied as foliar or soil remained as a nanoparticulate form in plant tissues of maize (Zea mays L.), ${ }^{44}$ soybean (Glycine max L. Merr.), ${ }^{45}$ water melon (Citrullus lanatus Thunb.), ${ }^{46}$ cucumber (Cucumis sativus L.), ${ }^{47}$ and pumpkin (Cucurbita maxima L.). ${ }^{48}$ However, the presence of biogenic reductants such as phenols, reducing sugars, and organic acids in plant cell may potentially convert the nanoparticulate form to ionic form. ${ }^{49,50}$

2.4. Nanoceria Effect on ROS, Lipid Peroxidation, and Antioxidant Enzyme Activity. Under drought conditions, nanoceria-sprayed plants exhibit significant $(P \leq 0.01)$ reductions in contents of $\mathrm{O}_{2}^{-}(41 \%$, Figure $4 \mathrm{a}), \mathrm{H}_{2} \mathrm{O}_{2}(36 \%$, Figure 4b), and malondialdehyde (MDA, a metric of lipid peroxidation) (37\%, Figure 4c) and increased activities of SOD (94\%, Figure 4d), CAT (117\%, Figure 4e), and POX (54\%, Figure 4f) compared to water-sprayed control plants (Figure $4 a-f)$. Under irrigated conditions, there were no significant differences in these parameters between water and nanoceria foliar-sprayed treatments (Figure $4 \mathrm{a}-\mathrm{f}$ ). Levels of ROS produced in the chloroplast electron transport chain are kept under control in nonstress conditions by antioxidants and antioxidant enzyme activity. ${ }^{51}$ However, drought increases the production and accumulation of $\mathrm{O}_{2}{ }^{-}$and $\mathrm{H}_{2} \mathrm{O}_{2}{ }^{32}$ and decreases the antioxidant enzyme activity. ${ }^{52}$ ROS accumulation that cannot be regulated by the antioxidant defense system results in oxidation of biomolecules including nucleic acids, proteins, and lipids. ${ }^{29-32}$ Nanoceria mimic SOD activity with a higher efficiency in converting $\mathrm{O}_{2}^{-}$to $\mathrm{H}_{2} \mathrm{O}_{2}$ than SOD. ${ }^{5}$ Large surface area of nanoceria relative to its volume alternates between $\mathrm{Ce}^{4+}$ and $\mathrm{Ce}^{3+}$ oxidation states with a redox capacity comparable to that of oxygen ${ }^{53}$ leading to redox reactions ${ }^{54}$ that scavenge the ROS produced under drought. Previous studies have demonstrated the ROS scavenging ability of bare and surface-modified nanoceria in plants, cell culture, and animal models by mimicking the antioxidant enzyme activity. ${ }^{2,5,55-58}$ Our results indicate that nanoceria-sprayed sorghum was highly efficient in scavenging ROS and increased antioxidant enzyme activity resulting in lower lipid peroxidation (Figure 4c).

2.5. Nanoceria Increase Pollen Germination and Seed Yield under Drought. Foliar spray of nanoceria in sorghum plants under drought increased seed yield plant $^{-1}$ (31\%) compared to water-sprayed plants (Figure 5d). Under irrigated conditions, there was no significant difference between water and nanoceria foliar-sprayed treatments on seed yield plant ${ }^{-1}$ (Figure 5d). Seed yield plant ${ }^{-1}$ is a product of number of seed panicle $^{-1}$ (seed-set percent) and individual seed weight. In this study, the seed-set percent was decreased (24\%) by drought relative to irrigated conditions, whereas foliar spray of nanoceria improved the seed-set percent (13\%) relative to water spray (Figure $5 b$ ). The seed-set percent is primarily the result of floret fertility, which is dependent on pollen and pistil functions, namely, pollination, fertilization, and grain formation. ${ }^{59}$ Drought during the sorghum gametogenesis stage decreased the pollen germination percent $(31 \%)$ compared to irrigated conditions, whereas foliar spray of nanoceria protected pollen germination (10\%) under drought relative to water spray (Figure 5a; Figure S1). Previous studies on other crop species including rice (Oryza sativa L.), ${ }^{60}$ wheat (Triticum aestivum L.), ${ }^{61}$ and chickpea (Cicer arietinum L.) ${ }^{62}$ have shown that drought decreases the pollen germination percent, leading to decreased pod/seed-set percentage. The reduction in pollen fertility under abiotic stresses including drought could be a consequence of altered carbohydrate metabolism in the developing reproductive tissue ${ }^{59,61}$ and ROS production. ${ }^{63-65}$ Scavenging of ROS produced under drought stress by nanoceria can protect lipid membrane damage in 


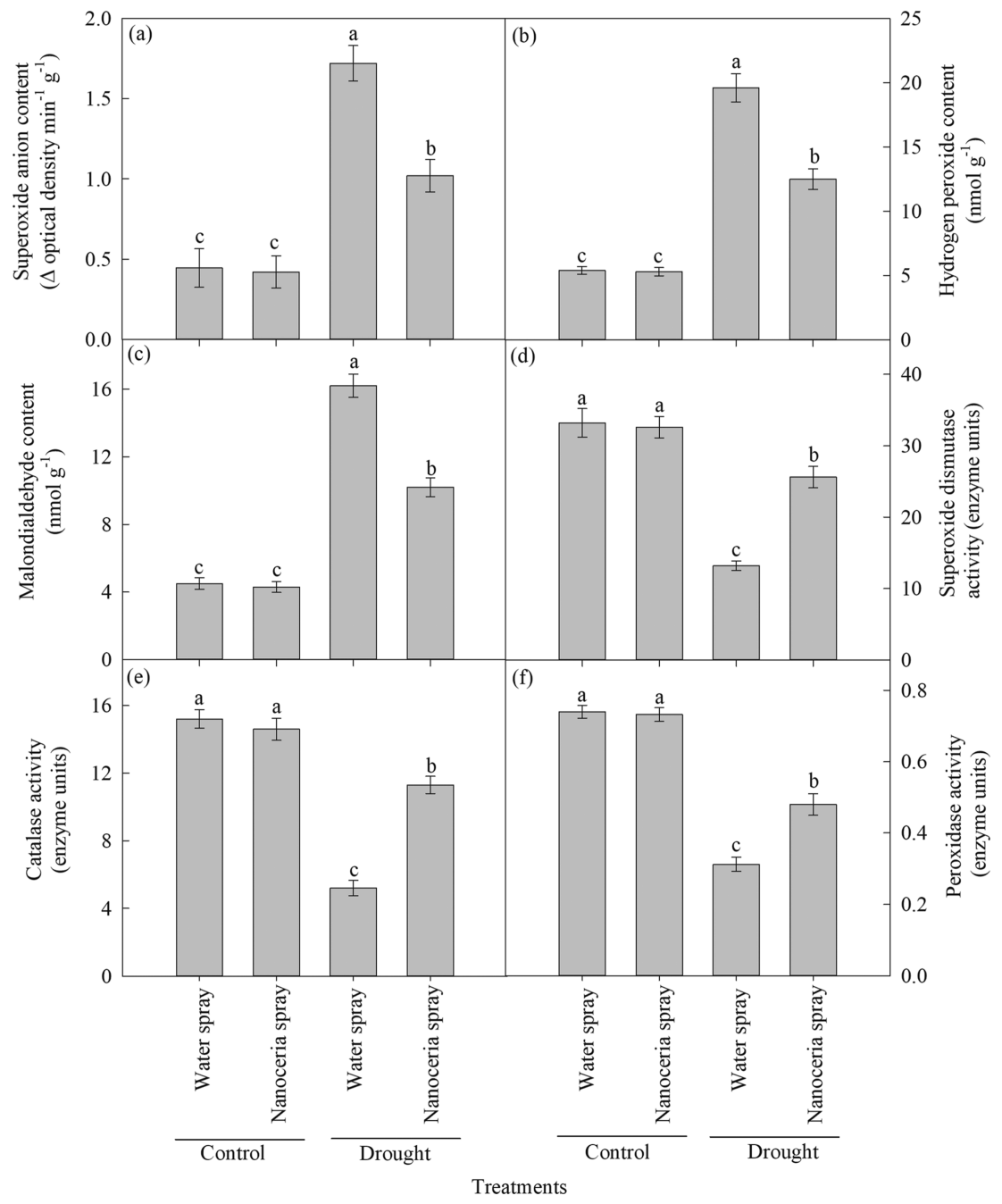

Figure 4. Foliar spray of nanoceria under drought has alleviated oxidative stress. (a) Superoxide anion content (change in OD min $\left.{ }^{-1} \mathrm{~g}^{-1}\right),(\mathrm{b})$ hydrogen peroxide content $\left(\mathrm{nmol} \mathrm{g}^{-1}\right)$, (c) MDA content $\left(\mathrm{nmol} \mathrm{g}^{-1}\right)$, (d) SOD activity (enzyme units), (e) CAT activity (enzyme units), and (f) POX activity (enzyme units). Each value is the mean \pm SE of 10 independent measurements (five replications $\times$ two experiment). Means with different letters are significantly different at $P \leq 0.05$.

reproductive tissues (both pollen and pistil), resulting in the increased seed-set percentage. Lower seed-set percentage (lower grain number) may be compensated by higher individual seed weight (due to the availability of more assimilates to the developing grain). However, in this study, there was no influence on individual seed weight (Figure 5c), as the drought was imposed for $21 \mathrm{~d}$ from panicle initiation, during the period affecting grain number through pollen viability but not individual seed weight. Thus, the increased seed yield plant ${ }^{-1}$ by nanoceria under drought was associated with higher seed-set percent and increased seed numbers.

2.6. Nanoceria Enhance Leaf Photosynthetic Rates under Drought. Drought significantly $(P \leq 0.01)$ decreased chlorophyll index (8\%; Figure 6a), photosystem (PS) II quantum yield (12\%; Figure $6 \mathrm{~b})$, stomatal conductance $(20 \%$; Figure $6 \mathrm{c}$ ), and carbon assimilation rates (23\%; Figure $6 \mathrm{~d}$ ) compared to irrigated controls. However, nanoceria foliar spray increased chlorophyll index (5\%; Figure 6a), PSII quantum yield ( $8 \%$; Figure $6 \mathrm{~b})$, stomatal conductance (7\%; Figure $6 \mathrm{c}$ ), and carbon assimilation rates (16\%; Figure $6 \mathrm{~d}$ ) compared to water-sprayed plants. Stomata control the exchange of water vapor and $\mathrm{CO}_{2}$, between the interior of the leaf and the atmosphere. ${ }^{66}$ Under drought, the generation of $\mathrm{H}_{2} \mathrm{O}_{2}{ }^{67}$ activates abscisic acid signaling pathway leading to closure of stomata. ${ }^{68}$ However, in the nanoceria-sprayed plants, decreased contents of $\mathrm{H}_{2} \mathrm{O}_{2}$ (Figure $6 \mathrm{~b}$ ) could have downregulated chloroplast $\mathrm{H}_{2} \mathrm{O}_{2}$-mediated stomatal closure. Drought alters the carbon fixation metabolism by a combination of both stomatal and nonstomatal limitations. ${ }^{19-21}$ In this study, the relative contribution of stomatal limitations, that is, stomatal conductance $(\sim 20 \%)$ was greater than the nonstomatal limitations, namely, quantum yield of PSII $(\sim 12 \%)$ toward decreasing the photosynthetic rate under drought. ${ }^{69}$ The stomatal limitations may promote an imbalance between PSII photochemistry and electron requirement for photosynthesis, eventually leading to an overexcitation and damage to PSII reaction centers. ${ }^{70}$ The ROS is involved in chlorophyll degradation and damage of chloroplast proteins and membranes, resulting in decreased photosynthetic rates. ${ }^{71}$ Nanoceria catalyze the quenching of ROS produced in chloroplasts by the oxygen vacancies in the $\mathrm{CeO}_{2}$ lattice structure, ${ }^{3}$ leading to improved photosynthesis and chlorophyll content index.

Leaf morphology analysis indicated that under drought, water-sprayed plants exhibit cuticle wax disintegration (Figure 7c). However, the nanoceria-sprayed plants had intact 


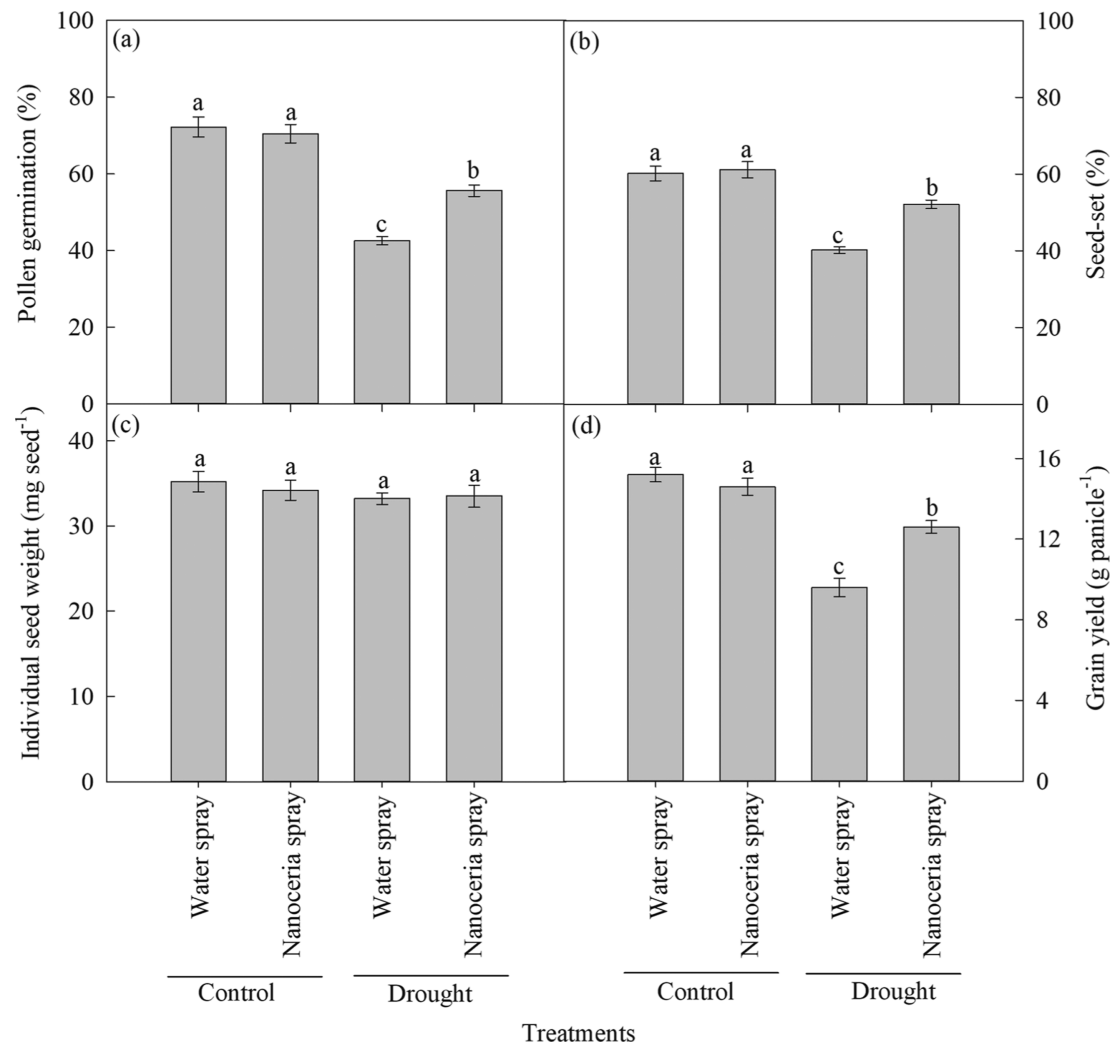

Figure 5. Improvement of seed-set percent by foliar spray of nanoceria under drought. (a) Pollen germination percent, (b) seed-set percent, (c) individual seed weight $\left(\mathrm{mg} \mathrm{seed}^{-1}\right)$, and $(\mathrm{d})$ grain yield $\left(\mathrm{g}\right.$ panicle $\left.{ }^{-1}\right)$. Each value is the mean \pm SE of 10 independent measurements (five replications $\times$ two experiment). Means with different letters are significantly different at $P \leq 0.05$.

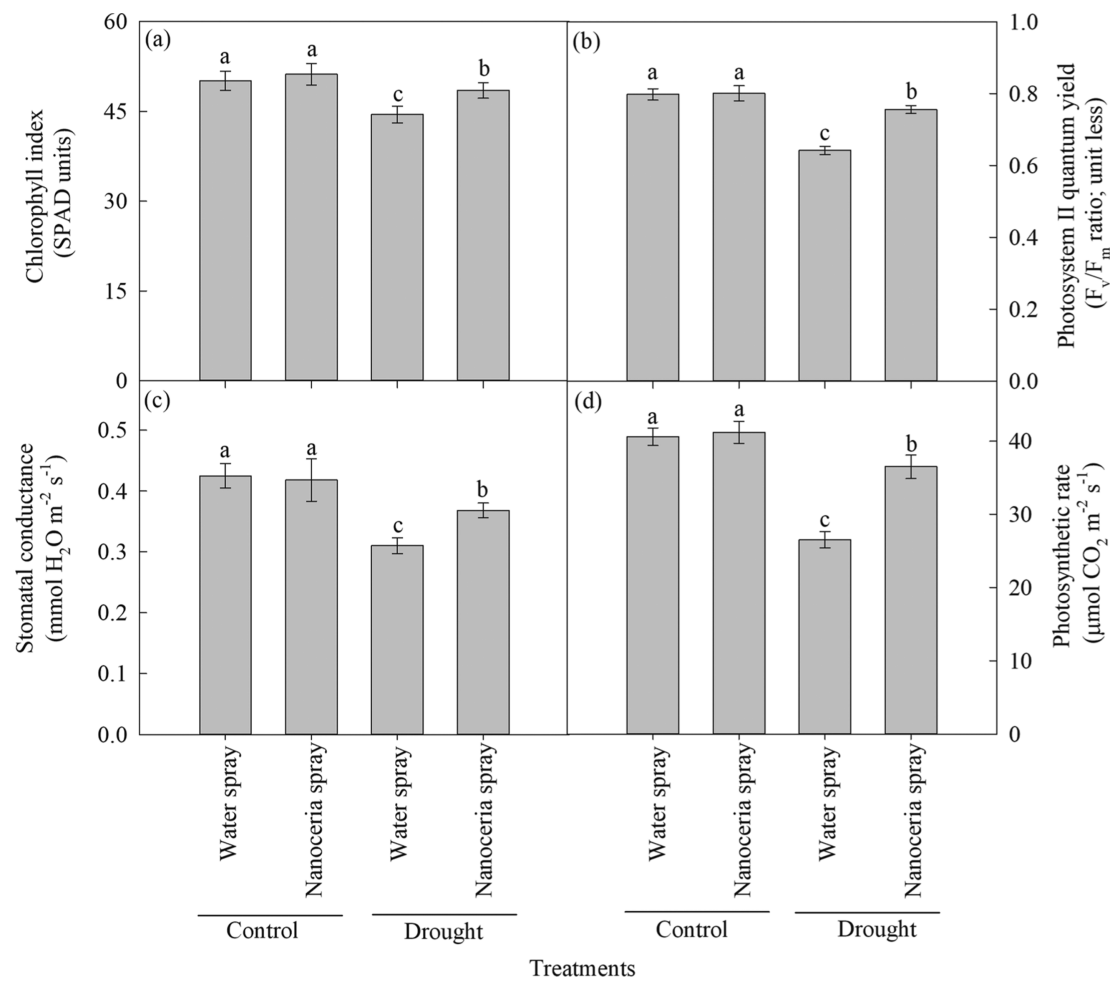

Figure 6. Foliar spray of nanoceria under drought has improved the carbon assimilation rates. (a) Chlorophyll index (SPAD units), (b) PSII quantum yield $\left(F_{\mathrm{v}} / F_{\mathrm{m}}\right.$ ratio; unit less), (c) stomatal conductance $\left(\mathrm{mmol} \mathrm{H}_{2} \mathrm{O} \mathrm{m}^{-2} \mathrm{~s}^{-1}\right)$, and (d) carbon assimilation rates $\left(\mu \mathrm{mol} \mathrm{CO} \mathrm{CO}^{-2} \mathrm{~s}^{-1}\right)$. Each value is the mean \pm SE of 10 independent measurements (five replications $\times$ two experiment). Means with different letters are significantly different at $P \leq 0.05$. 

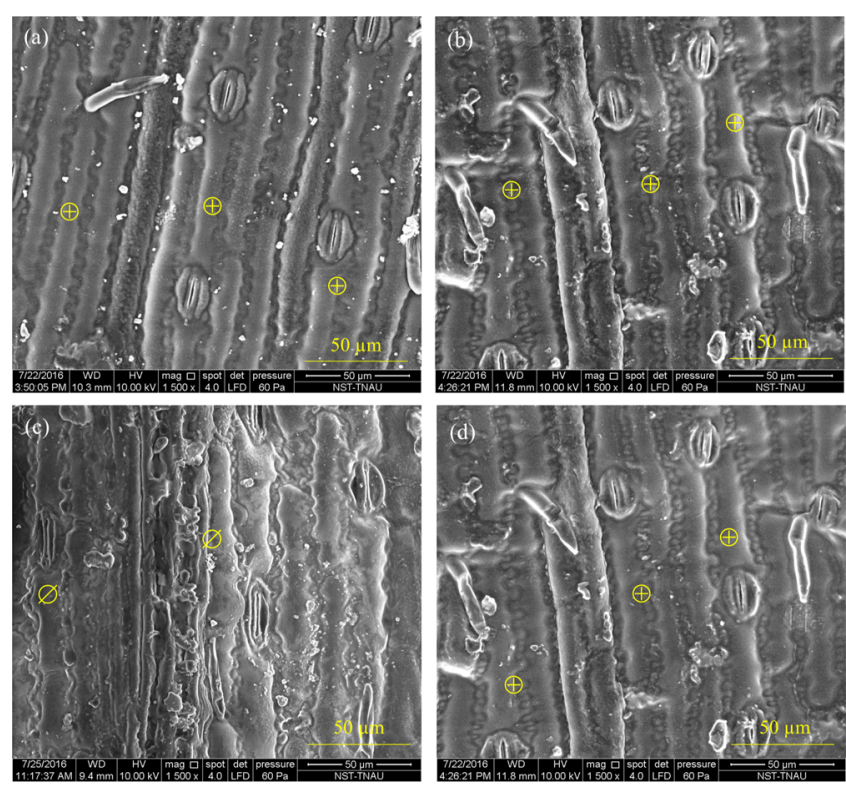

Figure 7. Maintenance of integrity of adaxial leaf epicuticular wax layer under drought by foliar spray of nanoceria. (a) Irrigated and water-sprayed, (b) irrigated and nanoceria-sprayed, (c) drought and water-sprayed, and $(\mathrm{d})$ drought and nanoceria-sprayed. $\oplus$ represents intact epicuticular wax, and $\varnothing$ shows disintegrated epicuticular wax.

epicuticular wax (Figure $7 \mathrm{~d}$ ). There was no variation in leaf mesophyll and vascular bundle cell anatomy by drought or foliar spray treatments (Figure S2). In sorghum, leaf epicuticular wax accumulation is positively correlated with the canopy temperature depression (ability of plant to cool itself) under drought. ${ }^{72}$ Drought-stressed plants treated with foliar-sprayed water exhibit disintegrated leaf cuticular wax layers. ${ }^{73}$ The intact epicuticular wax in nanoceria foliar-sprayed plants may have been due to increase in evapotranspiration leaf cooling associated with higher stomatal conductance.

\section{CONCLUSIONS}

Herein, we have demonstrated that under drought, foliar application of nanoceria protected and maintained carbon assimilation rates and pollen germination, resulting in higher seed-set percent and seed yield plant $^{-1}$. The increases in photosynthetic rates and pollen germination percentage were associated with efficient scavenging of ROS produced under drought stress by nanoceria, leading to decreased membrane lipid peroxidation. The toxicity assays performed using murine cell line culture indicate that the concentration for the $50 \%$ maximal effect [effective concentration $(\mathrm{EC})_{50}$ ] of nanoceria was more than $100 \mathrm{mg} \mathrm{L}^{-1}$. Thus, the levels of the nanoceria used in this study do not exhibit toxic effects on mammalian cells.

\section{MATERIALS AND METHODS}

4.1. Synthesis and Characterization of Nanoceria. Nanoceria were synthesized as detailed by Ketzial and Nesaraj $^{37}$ and Karakoti et al. ${ }^{74}$ using cerium(III) nitrate as a precursor. Multimode scanning probe microscopy (NTMDTNTEGRA, Russia) was used to study the surface topography height under ambient conditions $\left(25 \pm 2{ }^{\circ} \mathrm{C}\right)$ using a semicontact mode probe. The morphology and microstructure of the prepared nanoceria were studied by TEM (Tecnai Spirit G2, $120 \mathrm{kV}$, The Netherlands, an acceleration voltage of 120
$\mathrm{kV}$ ) and HRTEM (JEOL JEM 2100, Japan, an acceleration voltage of $200 \mathrm{kV})$, respectively. The selected-area electron diffraction (SAED) and EDX of the nanoceria were studied using HRTEM. The powder XRD analysis was done using a diffractometer (Rigaku Ultima IV XRD, Japan) in the $2 \theta$ range of $20^{\circ}-60^{\circ}$ utilizing $\mathrm{Cu} \mathrm{K} \alpha$ radiation $(40 \mathrm{kV}, 30 \mathrm{~mA}$, and $\lambda=$ $1.5405 \AA$ ), with a scan speed of $5^{\circ} \mathrm{min}^{-1}$. Crystallinity of the sample was obtained through the crystalline-amorphous peak deconvolution process using a Gaussian function. The FT-IR spectrum of nanoceria was recorded using JASCO FT-IR 6800, Japan, fitted with a diamond enabled attenuated total reflectance sample holder and a deuterated lanthanum $\alpha$ alanine-doped triglycine sulfate detector. The wavelength range was from 400 to $4000 \mathrm{~cm}^{-1}$. TGA of the samples was performed using a PerkinElmer STA 600 instrument.

4.2. Toxicity of Nanoceria to Mammalian Cells. The experiment was conducted in a completely randomized design. The mouse fibroblast L929 cell line was procured from ATCC, India, and used in MTT and DAPI assays with and without nanoceria as explained by Djanaguiraman et al. ${ }^{75}$ In the MTT assay, the cell viability was calculated as the ratio of optical density (OD) of the nanoceria-treated cells to OD of the control cells and expressed as percentage. For DAPI staining, the mouse fibroblast cell line was seeded in 96 -well plates $(5 \times$ $10^{3}$ cells per well) and cultured overnight to adhere on the well, after that different concentrations of nanoceria $(0,100$, 250, and $500 \mathrm{mg} \mathrm{L}^{-1}$ ) were added and left for $48 \mathrm{~h}$. After completion of the reaction, the fibroblast cells were washed and fixed using phosphate-buffered saline and $70 \%$ ethanol. Then, the cells were stained with $2.0 \mathrm{mg} \mathrm{L}^{-1}$ DAPI for $15 \mathrm{~min}$ and viewed under an inverted fluorescence microscope (Nikon Ti-SEclipse, Japan). The image shown is representative of 10 randomly observed fields.

4.3. Uptake of Nanoceria in Plants. River sand was collected, dried in air, and sieved through a $2 \mathrm{~mm}$ sieve (sieve number 10), and the fraction that does not pass through the sieve was discarded. The collected soil fraction $(<2 \mathrm{~mm})$ was again sieved through a $1 \mathrm{~mm}$ sieve (sieve number 20 ), and the fraction that does not pass through sieve (very coarse sand) was collected and soaked in aqua regia $\left(3: 1 \mathrm{HCl} / \mathrm{HNO}_{3}\right.$ acid ratio, $10 \mathrm{~mL}$ per $\mathrm{g}$ of sand) for 1 day and then washed thoroughly four times with double distilled water. Then, the soil was air-dried for $48 \mathrm{~h}$ and used for nanoceria uptake study as described by Djanaguiraman et al. ${ }^{75}$ In brief, the sorghum var. CO 30 was sown and grown in acid-washed sand by irrigating with one-quarter-strength Hoagland solution till 2 weeks. After that the plants were irrigated with either onequarter-strength Hoagland solution or one-quarter-strength Hoagland solution containing 50 or $100 \mathrm{mg} \mathrm{L}^{-1}$ nanoceria. The seedlings were maintained for 10 days and then uprooted carefully without any damage to the roots. The roots and shoots were dried in an oven at $40{ }^{\circ} \mathrm{C}$ for $72 \mathrm{~h}$, and their cerium content was determined using inductively coupled plasma-optical emission spectrometry (PerkinElmer optima, OPTIMA 2000 DV, Waltham, MA) following an established procedure. $^{76}$

4.4. Impact of Nanoceria on Sorghum Plants under Drought. 4.4.1. Crop Husbandry. Two independent outdoor pot-culture experiments were conducted in a randomized complete block with a split plot treatment structure at Department of Nano Science and Technology, Tamil Nadu Agricultural University, Coimbatore $\left(11^{\circ} \mathrm{N} ; 77^{\circ} \mathrm{E} ; 426.7 \mathrm{~m}\right.$ MSL), India. The main and subplots were irrigation level and 
foliar sprays, respectively. The main plot had two levels (control: plants maintained at $100 \%$ pot capacity moisture; and drought stress: withholding water for $21 \mathrm{~d}$ ). The subplot had two levels (control: foliar spray of water and foliar spray of nanoceria at a concentration of $10 \mathrm{mg} \mathrm{L}^{-1}$ ). There were 10 pots (replications) for each treatment combination.

Sandy clay loam soil ( $\mathrm{pH}$ of 7.7 , electrical conductivity of $0.33 \mathrm{dS} \mathrm{m} \mathrm{m}^{-1}$, organic carbon of $0.54 \%$ ) was collected from university farm, air-dried, sieved $(<3-5 \mathrm{~mm}$ sieve size), homogenized, and filled in an earthen pot $(30 \mathrm{~cm}$ diameter and $15 \mathrm{~kg}$ capacity) having small hole at the bottom to drain excess water to a weight of $10 \mathrm{~kg}$. The soil was low in available nitrogen $\left(205 \mathrm{~kg} \mathrm{ha}^{-1}\right)$, high in available phosphorus $(25 \mathrm{~kg}$ $\left.\mathrm{ha}^{-1}\right)$, and potassium $\left(458 \mathrm{~kg} \mathrm{ha}^{-1}\right)$. Five seeds of sorghum var. CO 30 were sown in each pot at a depth of $3 \mathrm{~cm}$. After emergence, plants were thinned to three plants per pot until maturity. The crop was grown until imposition of drought as detailed by Djanaguiraman et al. ${ }^{63}$ At flag leaf visible stage (tip of the flag leaf is visible in the whorl, 50 days after sowing), the primary stalk/panicle was tagged to recording pollen germination, seed-set percentage, and seed yield plant ${ }^{-1}$. The flag and subtending leaves of the tagged plants were used for assessing various physiological and biochemical traits. The middle portion of the flag leaf was used for leaf anatomical studies. Till start of the booting stage (60 days after sowing), the plants were maintained under a moisture level of $100 \%$ pot capacity. After that, the water was withheld for 21 days for the drought treatment and the corresponding irrigated plants (control) were maintained under a moisture level of $100 \%$ pot capacity.

The plants in five pots were used for leaf physiological, biochemical, and anatomical studies. The other five pots were used for assessing pollen germination, seed-set percent, and seed yield plant ${ }^{-1}$. On the day of water withhold, the drought and irrigated plants were foliar-sprayed with water or $10 \mathrm{mg}$ $\mathrm{L}^{-1}$ of nanoceria. Foliar spray of water or nanoceria was done once. Each pot was sprayed with $600 \mathrm{~mL}$ of spray solution, that is, $6 \mathrm{mg}$ of nanoceria for three plants ${ }^{-1}$. Previous studies and present murine cell line toxicity assays have shown that $\mathrm{LD}_{50}$ for nanoceria is more than $100 \mathrm{mg}$ of nanoceria $\mathrm{L}^{-1}$. A 10 times lower value of $\mathrm{LD}_{50}\left(10 \mathrm{mg} \mathrm{L}^{-1}\right)$ was used as nanoceria concentration for foliar spray treatments. After 21 days of drought, the plants were irrigated to $100 \%$ pot capacity and maintained till physiological maturity. The control plants were maintained under $100 \%$ pot capacity from sowing to physiological maturity.

4.4.2. Chlorophyll Index, Quantum Yield of PSII, and Leaf Gas Exchange. The chlorophyll index, PSII fluorescence, and leaf gas exchange were recorded on the attached, fully expanded flag leaves of tagged plants at midday (between 10:00 and 14:00 h), as described in Djanaguiraman et al. ${ }^{75}$ The photosynthetic rate and stomatal conductance were recorded using a portable photosynthesis system (LI-6400, LICOR, Lincoln, Nebraska, USA). The $\mathrm{CO}_{2}$ concentration in the leaf chamber of the photosynthesis system was set to $400 \mu \mathrm{mol}$ $\mathrm{mol}^{-1}$, with a flow rate of $500 \mu \mathrm{mol} \mathrm{s}{ }^{-1}$ and a light intensity of $1500 \mu \mathrm{mol} \mathrm{m} \mathrm{m}^{-2} \mathrm{~s}^{-1}$ of photosynthetically active radiation supplied by red-blue light-emitting diode. The measurements were recorded at ambient relative humidity and temperature.

4.4.3. ROS and MDA Content. At the anthesis stage, the flag and the subtending leaves were excised from the tagged plants between 11:00 and 13:00 $\mathrm{h}$ and immediately frozen in liquid nitrogen, transported to laboratory, and stored in $-20{ }^{\circ} \mathrm{C}$ until further analysis. Superoxide anion was estimated according to Chaitanya and Naithani ${ }^{77}$ and expressed as change in OD $\min ^{-1} \mathrm{~g}^{-1}$ on fresh weight (FW) basis. The frozen leaf samples were homogenized in $5 \mathrm{~mL}$ of ice-cold 0.2 mol sodium phosphate buffer $\mathrm{pH} 7.2$ containing $10^{-3}$ mol diethyl dithiocarbamate. The homogenate was immediately centrifuged for $1 \mathrm{~min}$ at $3000 \mathrm{~g}$, and the superoxide anion was measured using nitroblue tetrazolium chloride $\left(2.5 \times 10^{-4}\right.$ mol). The $\mathrm{H}_{2} \mathrm{O}_{2}$ levels were measured by following the method described by Patterson et al. ${ }^{78}$ using $20 \%$ titanium chloride reagent and expressed in $\mathrm{nmol} \mathrm{g} \mathrm{g}^{-1} \mathrm{FW}$. The lipid peroxidation was determined by MDA content produced by thiobarbitaric acid as described by Behera et al. ${ }^{79}$ expressed as MDA content in $\mathrm{nmol} \mathrm{g}^{-1}$ FW. Briefly, the frozen leaf samples were homogenized in $5 \mathrm{~mL}$ of $0.1 \%$ trichloroacetic acid, after that the homogenate was centrifuged for $5 \mathrm{~min}$ at $10000 \mathrm{~g}$. From the supernatant, $0.3 \mathrm{~mL}$ was taken and mixed with $1.2 \mathrm{~mL}$ of $0.5 \%$ thiobarbitaric acid prepared in $20 \%$ trichloroacetic acid and incubated in a water bath maintained at $95{ }^{\circ} \mathrm{C}$ for $30 \mathrm{~min}$. The reaction was stopped by keeping the test tube in an icebath for $5 \mathrm{~min}$ and centrifuged for $10 \mathrm{~min}$ at $10000 \mathrm{~g}$. The absorbance at 532 and $600 \mathrm{~nm}$ was recorded using a UV-vis spectrophotometer (SPECORD PLUS 210, Analytikjena, Jena, Germany). The detailed procedure of quantification of oxidants and membrane damage was available elsewhere. ${ }^{80}$

4.4.4. Antioxidant Enzyme Activity. The frozen leaf samples were homogenized in ice-cold Tris- $\mathrm{HCl}$ buffer $\mathrm{pH}$ 7.8 containing $1 \mathrm{mM}$ ethylene diamine tetraacetic acid, $1 \mathrm{mM}$ dithiotreitol, and $5 \mathrm{~mL}$ of $4 \%$ polyvinyl pyrrolidone $\mathrm{g}^{-1} \mathrm{FW}$. The homogenate was centrifuged at $20000 \mathrm{~g}$ at $4{ }^{\circ} \mathrm{C}$. The supernatant was used to measure SOD, CAT, and POX enzyme activity. SOD was determined as explained by Beyer and Fridovich, ${ }^{81}$ using a SOD assay kit (19160 SOD, SigmaAldrich, St. Louis, Missouri, USA) according to manufacturer's instructions. One unit of SOD is the amount of enzyme needed to obtain $50 \%$ dismutation of superoxide radical on leaf FW basis and expressed as enzyme units. The CAT activity was quantified by $\mathrm{Aebi}^{82}$ by monitoring the decline in the absorbance at $240 \mathrm{~nm}$ because of decomposition of $\mathrm{H}_{2} \mathrm{O}_{2}$. One enzyme unit was the amount of CAT enzyme that decomposes $1.0 \mu \mathrm{mol} \mathrm{H}_{2} \mathrm{O}_{2} \mathrm{~min}^{-1} \mathrm{~g}^{-1}$ of tissue on leaf FW basis and expressed as enzyme units. The POX activity was quantified by Gerbling et al. $^{83}$ The hydrogen peroxidedependent oxidation of ascorbate was monitored by a decrease in absorbance at $290 \mathrm{~nm}$ after addition of $\mathrm{H}_{2} \mathrm{O}_{2}$. One enzyme unit was the amount of POX enzyme that oxidizes $1.0 \mu \mathrm{mol}$ ascorbate $\min ^{-1} \mathrm{~g}^{-1}$ of tissue on leaf FW basis and expressed as enzyme units. Detailed procedure of enzyme extraction and method of quantification were explained in Jincy et al. ${ }^{80}$

4.4.5. Leaf Anatomical Studies. To determine the effect of water and nanoceria foliar spray on epicuticular wax integrity and leaf anatomy, the flag leaf was collected on the day of anthesis and immediately dipped in supercooled ethanol. The middle portions of leaf were cut into small size using a surgical knife. The upper portion of the leaf was placed on the double stick carbon tape affixed to a carbon stub and viewed with a scanning electron microscope (SEM; Quanta 250, FEI, Hillsboro, Oregon, USA) in ESEM mode fitted with a large field detector (LFD). The SEM was operated at low vacuum, $10 \mathrm{kV}$, with a spot size of 4 and a pressure of $60 \mathrm{~Pa}$. The sample images were taken at $\times 1500$ magnification. Similarly, the cross-sectional area of the leaf was mounted by affixing in the vertical position and viewed with SEM in the ESEM mode 
fitted with a LFD. The SEM was operated at the above conditions, and the images were acquired at $\times 300$ magnification.

4.4.6. Pollen Germination, Seed-Set Percent, and Seed Yield Plant ${ }^{-1}$. At anthesis, pollen grains were collected as described elsewhere and germinated in the medium as explained by Djanaguiraman et al. ${ }^{63}$ The tagged panicles were harvested at physiological maturity, dried at $40{ }^{\circ} \mathrm{C}$ for 7 days, and hand-threshed. The seed-set percentage and seed yield plant $^{-1}$ were quantified according to Djanaguiraman et al. $^{63}$

4.5. Data Analyses. The data were analyzed using SAS program. The data on physiological, biochemical, yield components, and toxicity assay were analyzed using the PROC GLM procedure of SAS. The data from each experiment were statistically analyzed independently and found that there were no significant differences. Therefore, the data from both the experiments were pooled together for combined statistical analyses, and the mean responses are presented. The standard error was shown as an estimate of variability, and means of various variables were separated for significance by the LSD test at a probability level of 0.05 .

\section{ASSOCIATED CONTENT}

\section{S Supporting Information}

The Supporting Information is available free of charge on the ACS Publications website at DOI: 10.1021/acsomega.8b01894.

Effects of nanoceria on pollen germination and leaf mesophyll and vascular bundle cell anatomy under different treatments (PDF)

\section{AUTHOR INFORMATION}

\section{Corresponding Author}

*E-mail: vara@ksu.edu. Phone: +1 785532 3746. Fax: +1 785 5326094.

\section{ORCID $\odot$}

Juan Pablo Giraldo: 0000-0002-8400-8944

Pagadala Venkata Vara Prasad: 0000-0001-6632-3361

\section{Author Contributions}

P.V.V.P. and M.D. conceived and designed the experiments. M.D. conducted experiments, collected, and analyzed data. M.D., P.V.V.P., R.N., and J.P.G. wrote the manuscript.

\section{Notes}

The authors declare no competing financial interest.

\section{ACKNOWLEDGMENTS}

The authors acknowledge the Indian Council of Agricultural Research (Consortia Research Platform on Nanotechnology) for financial support. The authors also acknowledge Tamil Nadu Agricultural University, India, for permitting M.D. to conduct postdoctoral research at Kansas State University, United States. We thank Feed the Future Sustainable Intensification Innovation Lab (grant no. AID-OAA-L-1400006) funded by United States Agency for International Development. Mention of trademark or proprietary product does not constitute a guarantee or warranty of the product by Kansas State University and does not imply its approval to the exclusion of other products, which may also be suitable. This is contribution no. 18-499-J from the Kansas Agricultural Experiment Station.

\section{REFERENCES}

(1) Ma, X.; Geiser-Lee, J.; Deng, Y.; Kolmakov, A. Interactions between engineered nanoparticles (ENPs) and plants: Phytotoxicity, uptake and accumulation. Sci. Total Environ. 2010, 408, 3053-3061.

(2) Boghossian, A. A.; Sen, F.; Gibbons, B. M.; Sen, S.; Faltermeier, S. M.; Giraldo, J. P.; Zhang, C. T.; Zhang, J.; Heller, D. A.; Strano, M. S. Application of nanoparticle antioxidants to enable hyperstable chloroplasts for solar energy harvesting. Adv. Energy Mater. 2013, 3, 881-893.

(3) Giraldo, J. P.; Landry, M. P.; Faltermeier, S. M.; McNicholas, T. P.; Iverson, N. M.; Boghossian, A. A.; Reuel, N. F.; Hilmer, A. J.; Sen, F.; Brew, J. A.; Strano, M. S. Plant nanobionics approach to augment photosynthesis and biochemical sensing. Nat. Mater. 2014, 13, 400408.

(4) Ivanov, V. K.; Shcherbakov, A. B.; Usatenko, A. V. Structuresensitive properties and biomedical applications of nanodispersed cerium dioxide. Russian Chem. Rev. 2009, 78, 855-871.

(5) Heckert, E. G.; Karakoti, A. S.; Seal, S.; Self, W. T. The role of cerium redox state in the SOD mimetic activity of nanoceria. Biomaterials 2008, 29, 2705-2709.

(6) Reed, K.; Cormack, A.; Kulkarni, A.; Mayton, M.; Sayle, D.; Klaessig, F.; Stadler, B. Exploring the properties and applications of nanoceria: is there still plenty of room at the bottom? Environ. Sci: Nano 2014, 1, 390-405.

(7) Wu, H.; Tito, N.; Giraldo, J. P. Anionic cerium oxide nanoparticles protect plant photosynthesis from abiotic stress by scavenging reactive oxygen species. ACS Nano 2017, 11, 1128311297.

(8) Pulido-Reyes, G.; Rodea-Palomares, I.; Das, S.; Sakthivel, T. S.; Leganes, F.; Rosal, R.; Seal, S.; Fernández-Piñas, F. Untangling the biological effects of cerium oxide nanoparticles: the role of surface valence states. Sci. Rep. 2015, 5, 15613.

(9) IPCC. Climate Change 2014: Synthesis Report. Contribution of Working Groups I, II and III to the Fifth Assessment Report of the Intergovernmental Panel on Climate Change; Pachauri, R. K., Meyer, L. A., Eds.; IPCC: Geneva, Switzerland, 2014; p 151.

(10) Stone, L. R.; Schlegel, A. J. Yield-water supply relationships of grain sorghum and winter wheat. Agron. J. 2006, 98, 1359-1366.

(11) Tack, J.; Lingenfelser, J.; Jagadish, S. V. K. Disaggregating sorghum yield reductions under warming scenarios exposes narrow genetic diversity in US breeding programs. Proc. Natl. Acad. Sci. U.S.A. 2017, 114, 9296-9301.

(12) Lobell, D. B.; Hammer, G. L.; Chenu, K.; Zheng, B.; McLean, G.; Chapman, S. C. The shifting influence of drought and heat stress for crops in northeast Australia. Glob. Chang. Biol. 2015, 21, 41154127.

(13) Srivastava, A.; Naresh Kumar, S.; Aggarwal, P. K. Assessment on vulnerability of sorghum to climate change in India. Agric. Ecosyst. Environ. 2010, 138, 160-169.

(14) Blanc, E. The impact of climate change on crop yields in SubSaharan Africa. Am. J. Climate Change 2012, 01, 1-13.

(15) Butt, T. A.; McCarl, B. A.; Angerer, J.; Dyke, P. T.; Stuth, J. W. The economic and food security implications of climate change in Mali. Climatic Change 2005, 68, 355-378.

(16) Chaves, M. M.; Costa, J. M.; Zarrouk, O.; Pinheiro, C.; Lopes, C. M.; Pereira, J. S. Controlling stomatal aperture in semi-arid regions-The dilemma of saving water or being cool? Plant Sci. 2016, 251, 54-64.

(17) Ouyang, W.; Struik, P. C.; Yin, X.; Yang, J. Stomatal conductance, mesophyll conductance, and transpiration efficiency in relation to leaf anatomy in rice and wheat genotypes under drought. J. Exp. Bot. 2017, 68, 5191-5205.

(18) Chaves, M. M.; Oliveira, M. M. Mechanisms underlying plant resilience to water deficits: prospects for water-saving agriculture. J. Exp. Bot. 2004, 55, 2365-2384.

(19) Tezara, W.; Mitchell, V. J.; Driscoll, S. D.; Lawlor, D. W. Water stress inhibits plant photosynthesis by decreasing coupling factor and ATP. Nature 1999, 401, 914-917. 
(20) Lawlor, D. W.; Cornic, G. Photosynthetic carbon assimilation and associated metabolism in relation to water deficits in higher plants. Plant Cell Environ. 2002, 25, 275-294.

(21) Lawlor, D. W.; Tezara, W. Causes of decreased photosynthetic rate and metabolic capacity in water-deficient leaf cells: a critical evaluation of mechanisms and integration of processes. Ann. Bot. 2009, 103, 561-579.

(22) Campos, H.; Cooper, M.; Habben, J. E.; Edmeades, G. O.; Schussler, J. R. Improving drought tolerance in maize: a view from industry. Field Crops Res. 2004, 90, 19-34.

(23) Lopes, M. S.; Araus, J. L.; van Heerden, P. D. R.; Foyer, C. H. Enhancing drought tolerance in C4 crops. J. Exp. Bot. 2011, 62, $3135-3153$

(24) Warren, C. R. Stand aside stomata, another actor deserves centre stage: the forgotten role of the internal conductance to $\mathrm{CO}_{2}$ transfer. J. Exp. Bot. 2008, 59, 1475-1487.

(25) Fracasso, A.; Trindade, L.; Amaducci, S. Drought tolerance strategies highlighted by two Sorghum bicolor races in a dry-down experiment. J. Plant Physiol. 2016, 190, 1-14.

(26) Fracasso, A.; Magnanini, E.; Marocco, A.; Amaducci, S. Realtime determination of photosynthesis, transpiration, water-use efficiency and gene expression of two Sorghum bicolor (Moench) genotypes subjected to dry-down. Front. Plant Sci. 2017, 8, 932.

(27) Asada, K. Production and scavenging of reactive oxygen species in chloroplasts and their functions. Plant Physiol. 2006, 141, 391-396.

(28) Miller, G.; Suzuki, N.; Ciftci-Yilmaz, S.; Mittler, R. Reactive oxygen species homeostasis and signalling during drought and salinity stresses. Plant Cell Environ. 2010, 33, 453-467.

(29) Mittler, R. Oxidative stress, antioxidants and stress tolerance. Trends Plant Sci. 2002, 7, 405-410.

(30) Gill, S. S.; Tuteja, N. Reactive oxygen species and antioxidant machinery in abiotic stress tolerance in crop plants. Plant Physiol. Biochem. 2010, 48, 909-930.

(31) Mittler, R. ROS are good. Trends Plant Sci. 2017, 22, 11-19. (32) Noctor, G.; Mhamdi, A.; Foyer, C. H. The roles of reactive oxygen metabolism in drought: not so cut and dried. Plant Physiol. 2014, 164, 1636-1648.

(33) Robinson, J. M.; Bunce, J. A. Influence of drought-induced water stress on soybean and spinach leaf ascorbate-dehydroascorbate level and redox status. Int. J. Plant Sci. 2000, 161, 271-279.

(34) Phoka, S.; Laokul, P.; Swatsitang, E.; Promarak, V.; Seraphin, S.; Maensiri, S. Synthesis, structural and optical properties of $\mathrm{CeO}_{2}$ nanoparticles synthesized by a simple polyvinyl pyrrolidone (PVP) solution route. Mater. Chem. Phys. 2009, 115, 423-428.

(35) Trujillo-Reyes, J.; Vilchis-Nestor, A. R.; Majumdar, S.; PeraltaVidea, J. R.; Gardea-Torresdey, J. L. Citric acid modifies surface properties of commercial $\mathrm{CeO}_{2}$ nanoparticles reducing their toxicity and cerium uptake in radish (Raphanus sativus) seedlings. J. Hazard. Mater. 2013, 263, 677-684.

(36) Dong, X.; Hong, G.; Yu, D. Synthesis and properties of cerium oxide nanometer powders by pyrolysis of amorphous citrate. J. Mater. Sci. Technol. 1997, 13, 113-116.

(37) Ketzial, J. J.; Nesaraj, A. S. Synthesis of $\mathrm{CeO}_{2} \mathrm{NPs}$ by chemical precipitation and the effects of a surfactant on the distribution of particles sizes. J. Ceram. Process. Res. 2011, 12, 74-79.

(38) Ji, Z.; Wang, X.; Zhang, H.; Lin, S.; Meng, H.; Sun, B.; George, S.; Xia, T.; Nel, A. E.; Zink, J. I. Designed synthesis of $\mathrm{CeO}_{2}$ nanorods and nanowires for studying toxicological effects of high aspect ratio nanomaterials. ACS Nano 2012, 6, 5366-5380.

(39) De Marzi, L.; Monaco, A.; De Lapuente, J.; Ramos, D.; Borras, M.; Di Gioacchino, M.; Santucci, S.; Poma, A. Cytotoxicity and genotoxicity of ceria nanoparticles on different cell lines in vitro. Int. J. Mol. Sci. 2013, 14, 3065-3077.

(40) Ramesh, A.; Ratla, N. N.; Indukuri, R.; Venkatesh, K.; Rao, S. $\mathrm{T}$. Acute and sub-acute oral toxicity assessment of the cerium oxide nanoparticles in Wistar rats. Int. J. Phytopharmacol. 2014, 5, 46-50.

(41) Zhu, Z.-J.; Wang, H.; Yan, B.; Zheng, H.; Jiang, Y.; Miranda, O. R.; Rotello, V. M.; Xing, B.; Vachet, R. W. Effect of surface charge on the uptake and distribution of gold nanoparticles in four plant species. Environ. Sci. Technol. 2012, 46, 12391-12398.

(42) Zhang, P.; Xie, C.; Ma, Y.; He, X.; Zhang, Z.; Ding, Y.; Zheng, L.; Zhang, J. Shape-dependent transformation and translocation of ceria nanoparticles in cucumber plants. Environ. Sci. Technol. Lett. 2017, 4, 380-385.

(43) Ma, Y.; Zhang, P.; Zhang, Z.; He, X.; Zhang, J.; Ding, Y.; Zhang, J.; Zheng, L.; Guo, Z.; Zhang, L.; Chai, Z.; Zhao, Y. Where does the transformation of precipitated ceria nanoparticles in hydroponic plants take place? Environ. Sci. Technol. 2015, 49, 10667-10674.

(44) Zhao, L.; Peralta-Videa, J. R.; Varela-Ramirez, A.; CastilloMichel, H.; Li, C.; Zhang, J.; Aguilera, R. J.; Keller, A. A.; GardeaTorresdey, J. L. Effect of surface coating and organic matter on the uptake of $\mathrm{CeO}_{2} \mathrm{NPs}$ by corn plants grown in soil: Insight into the uptake mechanism. J. Hazard. Mater. 2012, 225-226, 131-138.

(45) Hernandez-Viezcas, J. A.; Castillo-Michel, H.; Andrews, J. C.; Cotte, M.; Rico, C.; Peralta-Videa, J. R.; Ge, Y.; Priester, J. H.; Holden, P. A.; Gardea-Torresdey, J. L. In-situ synchrotron X-ray fluorescence mapping and speciation of $\mathrm{CeO}_{2}$ and $\mathrm{ZnO}$ nanoparticles in soil cultivated soybean (Glycine max). ACS Nano 2013, 7, 14151423.

(46) Wang, W.-N.; Tarafdar, J. C.; Biswas, P. Nanoparticle synthesis and delivery by an aerosol route for watermelon plant foliar uptake. J. Nanopart. Res. 2013, 15, 1417-1418.

(47) Zhang, Z.; He, X.; Zhang, H.; Ma, Y.; Zhang, P.; Ding, Y.; Zhao, Y. Uptake and distribution of ceria nanoparticles in cucumber plants. Metallomics 2011, 3, 816-822.

(48) Schwabe, F.; Schulin, R.; Limbach, L. K.; Stark, W.; Bürge, D.; Nowack, B. Influence of two types of organic matter on interaction of $\mathrm{CeO}_{2}$ nanoparticles with plants in hydroponic culture. Chemosphere 2013, 91, 512-520.

(49) Ma, Y.; He, X.; Zhang, P.; Zhang, Z.; Guo, Z.; Tai, R.; Xu, Z.; Zhang, L.; Ding, Y.; Zhao, Y.; Chai, Z. Phytotoxicity and biotransformation of $\mathrm{La}_{2} \mathrm{O}_{3}$ nanoparticles in a terrestrial plant cucumber (Cucumis sativus). Nanotoxicology 2011, 5, 743-753.

(50) Chai, P.; Ma, Y.; Zhang, Z.; He, X.; Zhang, J.; Guo, Z.; Tai, R.; Zhao, Y.; Chai, Z. Biotransformation of ceria nanoparticles in cucumber plants. ACS Nano 2012, 6, 9943-9950.

(51) Noctor, G.; Foyer, C. H. Ascorbate and glutathione: keeping active oxygen under control. Annu. Rev. Plant Physiol. Plant Mol. Biol. 1998, 49, 249-279.

(52) Zhang, J.; Kirkham, M. B. Drought-stress-induced changes in activities of superoxide dismutase, catalase, and peroxidase in wheat species. Plant Cell Physiol. 1994, 35, 785-791.

(53) Land, P. L. Defect equilibria for extended point defects, with application to nonstoichiometric ceria. J. Phys. Chem. Solids 1973, 34, $1839-1845$

(54) Conesa, J. C. Computer modeling of surfaces and defects on cerium dioxide. Surf. Sci. 1995, 339, 337-352.

(55) Asati, A.; Santra, S.; Kaittanis, C.; Nath, S.; Perez, J. M. Oxidase-like activity of polymer-coated cerium oxide nanoparticles. Angew. Chem., Int. Ed. Engl. 2009, 48, 2308-2312.

(56) Asati, A.; Kaittanis, C.; Santra, S.; Perez, J. M. pH-tunable oxidase-like activity of cerium oxide nanoparticles achieving sensitive fluorigenic detection of cancer biomarkers at neutral pH. Anal. Chem. 2011, 83, 2547-2553.

(57) Singh, R.; Singh, S. Role of phosphate on stability and catalase mimetic activity of cerium oxide nanoparticles. Colloids Surf., B 2015, $132,78-84$.

(58) Heckert, E. G.; Seal, S.; Self, W. T. Fenton-like reaction catalyzed by the rare earth inner transition metal cerium. Environ. Sci. Technol. 2008, 42, 5014-5019.

(59) Saini, H. S.; Westgate, M. E. Reproductive development in grain crops during drought. Adv. Agron. 2000, 68, 59-96.

(60) Sheoran, I. S.; Saini, H. S. Drought-induced male sterility in rice: changes in carbohydrate levels and enzyme activities associated with the inhibition of starch accumulation in pollen. Sex. Plant Reprod. 1996, 9, 161-169. 
(61) Saini, H. S. Effects of water stress on male gametophyte development in plants. Sex. Plant Reprod. 1997, 10, 67-73.

(62) Pang, J.; Turner, N. C.; Khan, T.; Du, Y.-L.; Xiong, J.-L.; Colmer, T. D.; et al. Response of chickpea (Cicer arietinum L.) to terminal drought: leaf stomatal conductance, pod abscisic acid concentration, and seed set. J. Exp. Bot. 2017, 68, No. erw153.

(63) Djanaguiraman, M.; Vara Prasad, P. V.; Murugan, M.; Perumal, R.; Reddy, U. K. Physiological differences among sorghum (Sorghum bicolor L. Moench) genotypes under high temperature stress. Environ. Exp. Bot. 2014, 100, 43-54.

(64) Djanaguiraman, M.; Perumal, R.; Jagadish, S. V. K.; Ciampitti, I. A.; Welti, R.; Prasad, P. V. V. Sensitivity of sorghum pollen and pistil to high-temperature stress. Plant, Cell Environ. 2018, 41, 10651082.

(65) Prasad, P. V. V.; Djanaguiraman, M. High night temperature decreases leaf photosynthesis and pollen function in grain sorghum. Funct. Plant Biol. 2011, 38, 993-1003.

(66) Ludlow, M. M. Strategies of response to water stress. In Structural and Functional Responses To Environmental Stresses: Water Shortage; Kreeb, K. H., Richter, H., Hinckley, T. M., Eds.; SPB Academic Publishing: London, 1989; pp 269-282.

(67) Suzuki, N.; Miller, G.; Salazar, C.; Mondal, H. A.; Shulaev, E.; Cortes, D. F. Temporal-spatial interaction between reactive oxygen species and abscisic acid regulates rapid systemic acclimation in plants. Plant Cell 2013, 25, 3553-3569.

(68) Sierla, M.; Waszczak, C.; Vahisalu, T.; Kangasjärvi, J. Reactive oxygen species in the regulation of stomatal movements. Plant Physiol. 2016, 171, 1569-1580.

(69) Escalona, J. M.; Flexas, J.; Medrano, H. Stomatal and nonstomatal limitations of photosynthesis under water stress in fieldgrown grapevines. Aust. J. Plant Physiol. 1999, 26, 421-433.

(70) Krause, G. H. Photoinhibition of photosynthesis. An evaluation of damaging and protective mechanisms. Physiol. Plant. 1988, 74, $566-574$.

(71) Smirnoff, N. Antioxidant systems and plant response to the environment. In Environment and Plant Metabolism: Flexibility and Acclimation; Smirnoff, N., Ed.; BIOS Scientific Publishers: Oxford, U.K., 1995; pp 217-243.

(72) Awika, H. O.; Hays, D. B.; Mullet, J. E.; Rooney, W. L.; Weers, B. D. QTL mapping and loci dissection for leaf epicuticular wax load and canopy temperature depression and their association with QTL for staygreen in Sorghum bicolor under stress. Euphytica 2017, 213, 207.

(73) Le Provost, G.; Domergue, F.; Lalanne, C.; et al. Soil water stress affects both cuticular wax content and cuticle-related gene expression in young saplings of maritime pine (Pinus pinaster Ait). BMC Plant Biol 2013, 13, 95.

(74) Karakoti, A. S.; Kuchibhatla, S. V. N. T.; Babu, K. S.; Seal, S. Direct synthesis of nanoceria in aqueous polyhydroxyl solutions. $J$. Phys. Chem. C 2007, 111, 17232-17240.

(75) Djanaguiraman, M.; Belliraj, N.; Bossmann, S. H.; Prasad, P. V. V. High-temperature stress alleviation by selenium nanoparticle treatment in grain sorghum. ACS Omega 2018, 3, 2479-2491.

(76) Paranthaman, R.; Vidyalakshmi, R.; Kumaravel, S. Optimization of digestion methods for mineral in spirullina by Inductively Coupled Plasma-Optical Emission Spectrometry. J. Adv. Pharm. Educ. Res. 2014, 4, 417-421.

(77) Chaitanya, K. S. K.; Naithani, S. C. Role of superoxide, lipid peroxidation and superoxide dismutase in membrane perturbation during loss of viability in seeds of Shorea robusta Gaertn. New Phytol. 1994, 126, 623-627.

(78) Patterson, B. D.; MacRae, E. A.; Ferguson, I. B. Estimation of hydrogen peroxide in plant extracts using titanium(IV). Anal. Biochem. 1984, 139, 487-492.

(79) Behera, T. H.; Panda, S. K.; Patra, H. K. Chromium ion induced lipid peroxidation in developing wheat seedlings: role of growth hormones. Indian J. Plant Physiol. 1999, 4, 236-238.

(80) Jincy, M.; Djanaguiraman, M.; Jeyakumar, P.; Subramanian, K. S.; Jayasankar, S.; Paliyath, G. Inhibition of phospholipase D enzyme activity through hexanal leads to delayed mango (Mangifera indica L.) fruit ripening through changes in oxidants and antioxidant enzymes activity. Sci. Hort. 2017, 218, 316-325.

(81) Beyer, W. F.; Fridovich, I. Assaying for superoxide dismutase activity: some large consequences of minor changes in conditions. Anal. Biochem. 1987, 161, 559-566.

(82) Aebi, H. Catalase. In Methods of Enzymatic Analysis, $2^{\text {nd }}$ ed.; Bergmeyer, H. U., Ed.; Verlag Chemie: Weinheim, 1983.

(83) Gerbling, K.-P.; Kelly, G. J.; Fischer, K.-H.; Latzko, E. Partial purification and properties of soluble ascorbate peroxidases from pea leaves. J. Plant Physiol. 1984, 115, 59-67. 